\title{
The Probability to Abolish Governance Provisions
}

\author{
Seoungpil Ahn (Corresponding author) \\ Sogang Business School, Sogang University \\ PA706, 35 Baekbeom-ro, Mapo-gu, Seoul 121-742, Korea \\ E-mail: spahn@sogang.ac.kr \\ Gwangheon Hong \\ Sogang Business School, Sogang University \\ PA711, 35 Baekbeom-ro, Mapo-gu, Seoul 121-742, Korea \\ E-mail: ghong@sogang.ac.kr
}

Received: November 8, 2015 Accepted: November 24, 2016

doi:10.5296/ber.v6i2.10269 URL: http://dx.doi.org/10.5296/ber.v6i2.10269

\begin{abstract}
The negative relation between governance indices and acquisition performance weakens in the post Sarbanes-Oxley Act (SOX) period. We examine whether firms remove anti-takeover provisions to eliminate the adverse impact of anti-takeover provisions. We find that strong external monitoring mechanisms such as the presence of public pension funds and large institutional investors leads firms to abolish some anti-takeover provisions and classified boards in particular. This partial elimination of anti-takeover provisions suggests a trade-off between benefit and cost of anti-takeover provisions.
\end{abstract}

Keywords: Anti-takeover provisions, Governance mechanism, Institutional investors, Industry competition

JEL classification: G30; G32; G34

\section{Introduction}

Gompers et al. (2003) document that a governance index-based trading strategy produced abnormal returns during the 1990s. Subsequent works confirm the adverse impact of anti-takeover provisions and firm performance. ${ }^{i}$ The causal link between anti-takeover provisions and firm performance suggests that investors during the 1990's did not fully recognize the impact of anti-takeover provisions on firm value. 
However, as market participants reflect the impact of anti-takeover provisions into stock prices, anti-takeover provisions become no longer associated with firm value in the subsequent period of 2002-2008. ${ }^{\text {ii }}$ Provided that the risk adjustment is adequate, the existence and disappearance of the association between anti-takeover provisions and firm value suggests that governance indices indeed caused abnormal return during the 1990s, but this abnormal return decayed over time as market participants learned about the causal relation.

One reason for the disappearance of the adverse impact of governance indices is that firms may voluntarily or be pressured to abolish harmful anti-takeover provisions. Our objective is to examine this probability to abolish anti-takeover provisions. Recent evidence shows that the pervasiveness of the governance-index effect depends on the strength of industry competition and the presence of active blockholders (Giroud and Mueller, 2010; Cremers and Nair, 2005; Kim and Lu , 2011).

Following these studies, we use pension fund ownership and industry competition as our main variables that are associated with the probability to abolish anti-takeover provisions. We show that the presence of public pension funds is associated with higher probability to abolish anti-takeover provisions. However, we fail to find evidence that firms facing strong product market competition are more likely to abolish anti-takeover provisions.

It is unknown when and which antitakeover provisions reduce firm value and thus, we do not assert that public pension funds and industry competition would eliminate entire anti-takeover provisions for all firms. Gompers et al. (2003) noted that “.... if anti-takeover provisions cause poor performance, then we might expect certain provisions to play a stronger role. In the absence of such a finding, we should wonder whether the results are driven by some other characteristic...." Analogously applying this insight to our test setting, we examine whether particular anti-takeover provisions are more likely to be eliminated by pension funds and industry competition.

The remainder of the paper is organized as follows. In Section 2, we discuss the related literature. Section 3 describes our sample selection procedure and provides descriptive statistics. Section 4 explores the influence of external monitoring mechanism on the probability to abolish anti-takeover provisions. Section 5 concludes the paper.

\section{Literature Review}

Public pension funds serve as an effective governance mechanism because they are free from conflicts of interests in monitoring firms (Gillan and Starks, 2000; Gompers and Metrik, 2001). Following previous studies in Cremers and Nair (2005) and Dittmar and Mahrt-Smith (2007), we use the percentage of shares held by the 19 largest public pension funds as measure of pension fund ownership. The pension fund ownership is divided into two categories: high pension and low pension from the median value. Institutional block holdings are used as the supplementary measure for the outside monitoring activities.

Product market competition works as an effective external governance mechanism because firms in competitive industries will eliminate managerial slack (Shleifer and Vishny, 1997; 
Bertrand and Mullainathan, 2003; Giroud and Mueller, 2010). We use the Herfindahl-Hirschman Index (HHI) to measure industry competition. Like Masulis et al. (2007), we also use industry sales expenses-to-sales ratio to capture the intensity of industry competition. Based on sample median values, we divide sample observations into strong and weak industry competition sub-groups.

Both public pension fund holdings and industry Herfindahl index is used to measure the monitoring activities coming from outside capital and product markets. These governance mechanisms are exogenous. These external monitoring mechanisms will affect the probability to remove harmful anti-takeover provisions.

\section{Research Design and Methods}

Sample firms include those covered in RiskMetrics database of antitakeover provisions in the period from 1996 to 2006. The IRRC governance database issued every two years starting from 1996 and we assume that firms had the same anti-takeover provisions as in the previous publication year during the years between two consecutive publications. We exclude very small firms with sales revenues of less than \$20 million and those lacking the required financial data from COMPUSTAT. We also exclude dual-class firms, real estate investment trusts.

The data consists of a panel data set that consists of firms that completed acquisitions in any year during the sample period. The IRRC reports governance indices every two years and thus we allow a one-year gap to measure firm-level changes in anti-takeover provisions. The changes in the number of anti-takeover provisions over non-overlapping two-year intervals is measured starting from the base years of 1996, 1998, 2000, 2002, and 2004. The sample consists of 5,050 firm-period observations. Our final sample consists of 5,050 firm-year observations between 1996 and 2006.

Table 1 reports description of our key variables. Anti-takeover provisions are measured with two index: BCF is the sum of six anti-takeover provisions as proposed by Benchuk, et al. (2009). This is our primary measure of the anti-takeover provisions adopted by a firm. We also use G-Index to measure the firm's adoption of anti-takeover provisions. G-Index is Gompers et al. (2003)'s governance index consists of 24 anti-takeover provisions.

Table 1. Corporate governance measures

\begin{tabular}{|l|l|l|}
\hline ATPs & Mean & Median \\
\hline BCF & 2.3 & 2.0 \\
\hline G-Index & 9.3 & 9.0 \\
\hline Public pension holdings & 0.02 & 0.02 \\
\hline Industy HHI & 0.18 & 0.15 \\
\hline
\end{tabular}

\section{Empirical Results and Discussion}

In this section, we examine the changes in BCF index for the extended time period. A cleaner 
test to prove the effect of external monitoring mechanisms is to clarify the channel through which they affects firm policy in a way that mitigates the adverse impact of anti-takeover provisions.

After controlling for deal and firm characteristics, we show that BCF index decreases over time when pension fund ownership is high. This suggests some monitoring pressure provided by public pension funds improves the quality of corporate governance.

\subsection{Strength of external monitoring mechanisms and changes in anti-takeover provisions}

Effective monitoring by external monitoring mechanisms suggests that firms are under pressure to shape an optimal governance structure. One channel through which strong external monitoring mechanism mitigates the harmful impact of anti-takeover provisions is to simply eliminate them when they are value-destroying. We thus predict that the presence of strong external monitoring mechanisms increases the probability of abolishing anti-takeover provisions.

For the entire sample consists of 5,050 firm-period observations, we test this possibility. Table 2 provides the changes in key variables in the subsequent year. From table 2, the BCF index increased by 0.2 provisions or about $10 \%$ in the two-year period. This is likely due to the backfilling of data in the IRRC, as noted by Gompers et al. (2003). For a majority of firms, the BCF index remains unchanged: It decreased in $6.3 \%$ of observations (264 cases) and increased in $22 \%$ of observations. Pension fund ownership show a statistically significant increase by $0.2 \%$ or $10 \%$ increase from the base year number, which suggests strengthening external monitoring over time. Industry competition, measured by average industry HHI, remains stable over the two-year internals.

Table 2. Changes in governance measures

\begin{tabular}{|l|l|l|}
\hline & Change in two years & $\%$ change \\
\hline BCF & 0.2 & $10 \%$ \\
\hline G-Index & 0.5 & $5 \%$ \\
\hline Public pension holdings & $0.2^{* * *}$ & $10 \%$ \\
\hline Industy HHI & 0.01 & $0.1 \%$ \\
\hline
\end{tabular}

***: Statistically significant at $1 \%$ significance level.

In table 3, we estimate the probability of a decrease in the BCF index using logit regression. The dependent variable takes the value of 1 if the BCF index decreases and zero otherwise. In model (1) of table 3, we introduce two dummy variables for the external governance with other controls. High Pension (High Competition) has the value of 1 if a firm has above (below) the median value of pension fund ownership (industry HHI) and zero, otherwise. The model includes a set of control variables in the model. Cash is cash and short-term investment divided by net assets. $M B$ is [the book value of assets minus (book value of equity and deferred tax) plus (the number of shares outstanding times fiscal year ending price)] divided by the book value of total assets. 
Table 3. Probability of a decrease in governance index

\begin{tabular}{|c|c|c|c|c|c|c|c|}
\hline & (1)Logit & (2)Logit & (3)Logit & (4)Logit & (5)Logit & (6) Probit & (7) $\operatorname{Cox}$ \\
\hline High Pension & $\begin{array}{l}-0.006 \\
(-0.04)\end{array}$ & $\begin{array}{l}0.364^{* *} \\
(2.56)\end{array}$ & & $\begin{array}{l}0.372^{* * *} \\
(2.38)\end{array}$ & $\begin{array}{l}0.348^{* * *} \\
(2.38)\end{array}$ & $\begin{array}{l}0.151^{* *} \\
(2.21)\end{array}$ & $\begin{array}{l}\text { 1.353** } \\
(2.26)\end{array}$ \\
\hline High Competition & $\begin{array}{l}-0.281 \\
(-1.06)\end{array}$ & $\begin{array}{l}-0.249 \\
(-0.81)\end{array}$ & & $\begin{array}{l}-0.204 \\
(-0.59)\end{array}$ & $\begin{array}{l}-0.274 \\
(-0.88)\end{array}$ & $\begin{array}{l}-0.129 \\
(-0.94)\end{array}$ & $\begin{array}{l}0.775 \\
(-0.88)\end{array}$ \\
\hline High Block Holdings & & & $\begin{array}{l}0.325^{* *} \\
(2.23)\end{array}$ & & & & \\
\hline High Sales Expenses & & & $\begin{array}{l}-0.474 \\
(-1.30) \\
\end{array}$ & & & & \\
\hline Cash & $\begin{array}{l}0.077 \\
(1.42)\end{array}$ & $\begin{array}{l}0.080 \\
(1.46)\end{array}$ & $\begin{array}{l}0.070 \\
(1.30)\end{array}$ & $\begin{array}{l}0.052 \\
(0.91)\end{array}$ & $\begin{array}{l}0.087 \\
(1.59)\end{array}$ & $\begin{array}{l}0.040 \\
(1.64)\end{array}$ & $\begin{array}{l}1.089 \\
(1.66)\end{array}$ \\
\hline MB & $\begin{array}{l}-0.017 \\
(-0.23)\end{array}$ & $\begin{array}{l}-0.013 \\
(-0.17)\end{array}$ & $\begin{array}{l}-0.012 \\
(-0.17)\end{array}$ & $\begin{array}{l}0.019 \\
(0.25)\end{array}$ & $\begin{array}{l}-0.020 \\
(-0.26)\end{array}$ & $\begin{array}{l}-0.013 \\
(-0.39)\end{array}$ & $\begin{array}{l}0.981 \\
(-0.28)\end{array}$ \\
\hline Ln(Assets) & $\begin{array}{l}0.101 \\
(1.32)\end{array}$ & $\begin{array}{l}0.090 \\
(1.17)\end{array}$ & $\begin{array}{l}0.116 \\
(1.51)\end{array}$ & $\begin{array}{l}0.182^{* * *} \\
(2.23) \\
\end{array}$ & $\begin{array}{l}0.049 \\
(0.59)\end{array}$ & $\begin{array}{l}0.016 \\
(0.44)\end{array}$ & $\begin{array}{l}1.018 \\
(0.26)\end{array}$ \\
\hline CashFlow & $\begin{array}{l}0.264 \\
(0.31)\end{array}$ & $\begin{array}{l}0.180 \\
(0.21)\end{array}$ & $\begin{array}{l}0.287 \\
(0.33)\end{array}$ & $\begin{array}{l}1.483 \\
(1.57)\end{array}$ & $\begin{array}{l}0.038 \\
(0.04)\end{array}$ & $\begin{array}{l}-0.055 \\
(-0.14)\end{array}$ & $\begin{array}{l}0.979 \\
(-0.03)\end{array}$ \\
\hline Debt & $\begin{array}{l}0.588 \\
(1.54)\end{array}$ & $\begin{array}{l}0.634 * \\
(1.65)\end{array}$ & $\begin{array}{l}0.511 \\
(1.32)\end{array}$ & $\begin{array}{l}0.452 \\
(1.12)\end{array}$ & $\begin{array}{l}0.720^{*} \\
(1.86)\end{array}$ & $\begin{array}{l}0.325^{*} \\
(1.92)\end{array}$ & $\begin{array}{l}1.973^{*} \\
(1.91)\end{array}$ \\
\hline CAPEX & $\begin{array}{l}0.597 \\
(0.36)\end{array}$ & $\begin{array}{l}0.450 \\
(0.27)\end{array}$ & $\begin{array}{l}0.637 \\
(0.38)\end{array}$ & $\begin{array}{l}2.528 \\
(1.47)\end{array}$ & $\begin{array}{l}0.307 \\
(0.18)\end{array}$ & $\begin{array}{l}0.125 \\
(0.17)\end{array}$ & $\begin{array}{l}1.363 \\
(0.20)\end{array}$ \\
\hline $\operatorname{Ln}($ Firm Age $)$ & $\begin{array}{l}0.231^{* * *} \\
(2.42) \\
\end{array}$ & $\begin{array}{l}0.230^{* * *} \\
(2.39) \\
\end{array}$ & $\begin{array}{l}0.245^{* *} \\
(2.56) \\
\end{array}$ & $\begin{array}{l}0.339 * * * \\
(3.30)\end{array}$ & $\begin{array}{l}0.233^{* * *} \\
(2.33) \\
\end{array}$ & \begin{tabular}{|l|}
$0.123 * * *$ \\
$(2.70)$ \\
\end{tabular} & $\begin{array}{l}1.141 \\
(1.27) \\
\end{array}$ \\
\hline Delaware & $\begin{array}{l}0.292^{* * *} \\
(2.14) \\
\end{array}$ & $\begin{array}{l}0.294 * * \\
(2.14) \\
\end{array}$ & $\begin{array}{l}0.287^{* *} \\
(2.09)\end{array}$ & $\begin{array}{l}0.231 \\
(1.56)\end{array}$ & $\begin{array}{l}0.299^{* *} \\
(2.16)\end{array}$ & $\begin{array}{l}0.148^{* * *} \\
(2.32) \\
\end{array}$ & $\begin{array}{l}\text { 1.313** } \\
(2.13)\end{array}$ \\
\hline S\&P Industrial Index & $\begin{array}{l}0.377^{*} \\
(1.81)\end{array}$ & $\begin{array}{l}0.414 * * \\
(1.99)\end{array}$ & $\begin{array}{l}0.369^{*} \\
(1.78)\end{array}$ & $\begin{array}{l}0.459^{* *} \\
(2.11)\end{array}$ & $\begin{array}{l}0.395^{*} \\
(1.86)\end{array}$ & $\begin{array}{l}0.197^{* * *} \\
(2.01)\end{array}$ & $\begin{array}{l}\text { 1.464** } \\
(1.98)\end{array}$ \\
\hline Exchange Listing & $\begin{array}{l}0.034 \\
(0.16)\end{array}$ & $\begin{array}{l}0.033 \\
(0.16)\end{array}$ & $\begin{array}{l}0.017 \\
(0.08)\end{array}$ & $\begin{array}{l}0.005 \\
(0.02)\end{array}$ & $\begin{array}{l}0.052 \\
(0.24)\end{array}$ & $\begin{array}{l}0.019 \\
(0.20)\end{array}$ & $\begin{array}{l}1.059 \\
(0.28)\end{array}$ \\
\hline$\overline{L n(\text { Delta })}$ & & & & & $\begin{array}{l}0.002 \\
(0.25)\end{array}$ & $\begin{array}{l}0.001 \\
(0.21)\end{array}$ & $\begin{array}{l}1.002 \\
(0.33)\end{array}$ \\
\hline$\overline{L n(\text { Vega })}$ & & & & & $\begin{array}{l}0.193 \\
(1.45)\end{array}$ & $\begin{array}{l}0.117 \\
(1.54)\end{array}$ & $\begin{array}{l}1.186 \\
(1.64)\end{array}$ \\
\hline Board Size & & & & & $\begin{array}{l}0.008 \\
(0.23) \\
\end{array}$ & \begin{tabular}{|l|}
0.000 \\
$(0.03)$ \\
\end{tabular} & $\begin{array}{l}1.011 \\
(0.35) \\
\end{array}$ \\
\hline Percent Independent & & & & & $\begin{array}{l}-0.545 \\
(-1.06) \\
\end{array}$ & $\begin{array}{l}-0.247 \\
(-1.05) \\
\end{array}$ & $\begin{array}{r}0.607 \\
(-1.06) \\
\end{array}$ \\
\hline CEO/Chair & & & & & $\begin{array}{l}0.240 \\
(1.42)\end{array}$ & $\begin{array}{l}0.097 \\
(1.26)\end{array}$ & $\begin{array}{l}1.254 \\
(1.45)\end{array}$ \\
\hline Intercept & $\begin{array}{l}-6.412 * * * \\
(-6.06)\end{array}$ & $\begin{array}{l}-6.566 * * * \\
(-6.10) \\
\end{array}$ & $\begin{array}{l}-6.596 * * * \\
(-6.03)\end{array}$ & $\begin{array}{l}-5.224 * * * \\
(-5.95)\end{array}$ & $\begin{array}{l}-6.129 * * * \\
(-5.26)\end{array}$ & $\begin{array}{l}-3.023 * * * \\
(-6.31)\end{array}$ & N.A. \\
\hline pseudo_R & 0.065 & 0.068 & 0.067 & 0.123 & 0.072 & 0.072 & 0.031 \\
\hline $\mathrm{N}$ & 5,050 & 5,050 & 5,050 & 1,973 & 5,050 & 5,050 & 5,050 \\
\hline
\end{tabular}

The numbers in parentheses are heteroscedasticity-robust z-statistics. All final variables are winsorized at the $1^{\text {st }}$ and $99^{\text {th }}$ percentiles. $* * *, * *$, and $*$ denote significance at the $1 \%, 5 \%$, and $10 \%$ levels, respectively.

Ln(Assets) is the natural log of book value of assets. CashFlow is (net income before extraordinary items plus depreciation minus capital expenditure) divided by the book value of assets. Debt is (long-term debt plus short-term debt) divided by (book value of assets minus 
current liabilities plus short-term debt. CAPEX is the capital expenditure divided by assets. Ln(Firm Age) is the natural log of firm age reported in CRSP. Delaware is a dummy variable having 1 if the firm is incorporated in Delaware and zero, otherwise. $S \& P$ Industrial index is a dummy variable having value of 1 if a firm is listed in the S\&P industrial index and zero, otherwise. Exchange Listing is is a dummy variable having value of 1 if a firm is listed in any major exchanges and zero, otherwise. $\operatorname{Ln}($ Delta) is a natural log of CEO delta, the sensitivity of CEO compensation to the change in stock price. $\operatorname{Ln}(\mathrm{Vega})$ is a natural log of CEO vega, the sensitivity of CEO compensation to the change in stock return volatility. Board size is the number of board members in a firm. Percent Independent is the percentage of independent directors in a board. CEO/Chair is the CEO-Chair duality.

From model (1) of table 3, the result shows that external governance are not associated with the probability of eliminating anti-takeover provisions. Perhaps, the trigger point at which external governance makes a difference is higher than the median.

Thus, in models (2)-(7), we redefine the external governance dummy variables based on the highest quartile value $(2.81 \%)$ of pension ownership and the lowest quartile value of industry HHI. In model 3, we use the highest quartile value (20.9\%) of block holdings and industry sales expenses.

In model (2), we find that the presence of pension funds increases the probability of removing anti-takeover provisions. The coefficient on High Pension is 0.364 and is significant at the conventional significance level. This translates into a marginal effect of $1.58 \%$ : High pension ownership increases the odds of removing anti-takeover provisions by $1.58 \%$. In model (3), we estimate a logit regression using institutional block holdings as an alternative to pension fund ownership. Again, we find that institutional block holdings increase the odds of removing anti-takeover provisions.

Considering the low frequency of a decrease in the BCF index, this low marginal effect is expected. We thus gauge the economic magnitude using conditional probability. Provided that a firm abolishes anti-takeover provisions, the conditional probability that the decrease in the $\mathrm{BCF}$ index comes from high-pension group is $44.4 \%$ higher than that for low pension group. We interpret these results as suggesting that the effective monitoring provided by pension funds promotes firms to remove value-destroying anti-takeover provisions. By contrast, firms facing weak external governance pressure will maintain suboptimal provisions. This explains the observed the negative association between BCF index and firm performance.

Industry competition and cash have an insignificant impact on the probability of removing anti-takeover provisions. Thus, these two factors do not trigger the change in a firm's policy to retain anti-takeover provisions. The insignificant result for industry competition implies that the influence of industry competition is routed through different channels than the adjustment of anti-takeover provisions. Alternatively, it may suggest that the effect of industry competition is spuriously driven by measurement errors and endogeneity problems.

In model (4), we re-estimate the probability of eliminating anti-takeover provisions excluding firms that have the same number of BCF provisions over the two-year intervals. The sample 
size reduces to 1,973 observations, but we continue to find that pension ownership increases the probability of removing anti-takeover provisions. The estimated marginal effect of pension ownership increases to $3.78 \%$ and the conditional probability is $46 \%$ under this specification. These results hold after controlling for CEO incentives and board structure in model (5) and using probit estimation in model (6).

In the logit and probit analyses, the change in the BCF index in each time batch is treated as an independent event, such as pension ownership in 1998 is related to the probability of removing anti-takeover provisions in 2000, but not in subsequent years. This assumption is true when pension holdings are time-series independent. The status of pension ownership is stable over time, however. For our sample, among those firms in the high pension group in $1996,91 \%$ are continuously classified in the high pension group throughout the entire sample period and among firms in the low pension group in 1996, 72\% are consistently classified into the low pension group. This suggests that pension ownership status in earlier years has an accumulated impact on the probability of removing anti-takeover provisions in later periods. It is for this reason that we do not conduct the change analysis.

To accommodate the time-varying nature of other control variables over the long-run, we estimate cumulative probability using a Cox Proportional Hazard model. Model (7) reports the hazard ratio, which indicates the conditional likelihood that a firm removes anti-takeover provisions in time period $t$, given that these provisions have survived through time ( $t-1)$. The result shows that high pension ownership increases the likelihood of removing anti-takeover provisions by $35.3 \%$ which is significant in economic magnitude.

We also find some positive effect of firm reputation in eliminating anti-takeover provisions. We use a firm's inclusion in the S\&P industrial index as a proxy for firm reputation because firms in the S\&P industrial index are well-known and are greatly exposed to public interests as well as financial analysts. In table 3, we measure firm reputation with the firm's inclusion in the $S \& P$ include a dummy variable set to 1 if a firm is included in the $S \& P$ industrial index in the year. In models (1)-(7), the inclusion in the S\&P industrial index consistently increases the probability of eliminating anti-takeover provisions. Thus, we conjecture that these well-recognized firms are vulnerable to public criticism in maintaining antitakeover provisions.

In sum, the results from table 3 indicate that public pension funds serve as an effective monitor in eliminating value-destroying anti-takeover provisions.

\subsection{The probability of abolishing individual provisions}

We further test the probability of removal for individual provision. When we check the frequency of removal in individual provisions, there are 85 cases of removal in classified boards, 68 cases in golden parachutes, 36 cases in limits in by-laws, 8 cases in limits in corporate charters, 127 cases in poison pills, and 31 cases in supermajority rules. We also note that there is a positive correlation in the removal frequencies across classified boards, poison pills, limits to amend bylaws, and super-majority rule. Because of the rareness of corporate charter amendment, we estimate the probability of removal for the remaining five 
provisions.

We estimate the probability of removal for individual anti-takeover provisions. Table 4 presents the result. In model (1), we use a logit model and estimate the probability to abolish classified boards when external governance forces are strong. The result shows that classified boards are most likely to be abolished when pension fund ownership is high. The positive coefficient on High Pension indicates that high pension fund ownership increases the probability of removal by $0.44 \%$, while the conditional probability of removal for high pension group is $64.8 \%$ higher than that for low pension group. The coefficients on High Pension are insignificant for other provisions in models (2)-(5). Firm size increases the probability of abolishing classified boards and limits in amending bylaws. Cash, CAPEX, and inclusion in the S\&P index are also associated with a higher probability of abolishing some anti-takeover provisions.

Focusing on classified boards, we introduce additional governance related variables including managerial incentives measured by delta and vega, board size, the percentage of independent directors in the boards, and an indicator variable to check the duality of CEO and the chairman of the board. In model (6), we continue to find a significant influence of pension funds in eliminating classified board structure.

In sum, we find that classified boards are most likely to be abolished when pension fund ownership is high. The result indicates that the conditional probability to abolish classified boards for firms with high pension ownership is $64.8 \%$ higher than that for firms with low pension ownership. The result thus indicates that effective monitoring by pension funds triggers the decision to abolish classified boards. Given that shareholder proposals sponsored by large institutional investors enhance the chance of success (Gillan and Starks, 2000), our result is consistent with the finding in Guo, Kruse, and Nohel (2008), who document that shareholder activism plays an important role in eliminating classified boards.

Thus, pension funds appear to target a particular anti-takeover provision. If pension funds view that classified boards entrench management, this illustrates one possible channel through which active pension funds act to enhance firm value by altering corporate governance practices. The remaining question is that why pension funds are not active enough to eliminate entire anti-takeover provisions if anti-takeover provisions are detrimental to firm value. 
Table 4. Probability of abolishing individual provision

\begin{tabular}{|c|c|c|c|c|c|c|c|}
\hline & $\begin{array}{l}\text { (1)Classified } \\
\text { Boards }\end{array}$ & $\begin{array}{l}\text { (2) Golden } \\
\text { Parachute }\end{array}$ & $\begin{array}{l}\text { (3) Limit } \\
\text { Bylaw }\end{array}$ & $\begin{array}{l}\text { (4)Poison } \\
\text { Pill } \\
\end{array}$ & $\begin{array}{l}\text { (5)Super } \\
\text { Majority }\end{array}$ & $\begin{array}{l}\text { (6)Classified } \\
\text { Boards }\end{array}$ & $\begin{array}{l}\text { (7)Classified } \\
\text { Boards-Cox }\end{array}$ \\
\hline High Pension & $\begin{array}{l}0.500 * * \\
(2.16)\end{array}$ & $\begin{array}{l}0.248 \\
(0.80)\end{array}$ & $\begin{array}{l}-0.162 \\
(-0.37) \\
\end{array}$ & $\begin{array}{l}0.212 \\
(0.98) \\
\end{array}$ & $\begin{array}{l}0.721 \\
(1.57) \\
\end{array}$ & $\begin{array}{l}0.507 * * \\
(2.03)\end{array}$ & $\begin{array}{l}1.606^{* *} \\
(1.97)\end{array}$ \\
\hline High Competition & $\begin{array}{l}0.547 \\
(1.06) \\
\end{array}$ & $\begin{array}{l}-0.325 \\
(-0.67)\end{array}$ & $\begin{array}{l}-0.338 \\
(-0.29)\end{array}$ & $\begin{array}{l}-0.479 \\
(-0.83)\end{array}$ & $\begin{array}{l}0.042 \\
(0.04)\end{array}$ & $\begin{array}{l}0.533 \\
(1.00)\end{array}$ & $\begin{array}{l}1.464 \\
(0.75)\end{array}$ \\
\hline Cash & $\begin{array}{l}-0.059 \\
(-0.59) \\
\end{array}$ & $\begin{array}{l}0.251 * * \\
(2.50)\end{array}$ & $\begin{array}{l}-0.129 \\
(-1.03) \\
\end{array}$ & $\begin{array}{l}0.069 \\
(0.79)\end{array}$ & $\begin{array}{l}0.237 \\
(1.26)\end{array}$ & $\begin{array}{l}-0.033 \\
(-0.33)\end{array}$ & $\begin{array}{l}0.979 \\
(-0.23)\end{array}$ \\
\hline $\mathrm{MB}$ & $\begin{array}{l}-0.105 \\
(-0.78)\end{array}$ & $\begin{array}{l}-0.079 \\
(-0.46)\end{array}$ & $\begin{array}{l}0.031 \\
(0.18)\end{array}$ & $\begin{array}{l}-0.046 \\
(-0.37) \\
\end{array}$ & $\begin{array}{l}0.067 \\
(0.30)\end{array}$ & $\begin{array}{l}-0.114 \\
(-0.79)\end{array}$ & $\begin{array}{l}0.908 \\
(-0.70)\end{array}$ \\
\hline $\operatorname{Ln}$ (Assets) & $\begin{array}{l}0.316 * * \\
(2.42)\end{array}$ & $\begin{array}{l}-0.088 \\
(-0.66)\end{array}$ & $\begin{array}{l}0.523 * * * \\
(2.72)\end{array}$ & $\begin{array}{l}0.082 \\
(0.93)\end{array}$ & $\begin{array}{l}0.167 \\
(0.82)\end{array}$ & $\begin{array}{l}0.225 \\
(1.62)\end{array}$ & $\begin{array}{l}1.241 \\
(1.64)\end{array}$ \\
\hline CashFlow & $\begin{array}{l}0.654 \\
(0.42)\end{array}$ & $\begin{array}{l}-0.169 \\
(-0.12)\end{array}$ & $\begin{array}{l}0.587 \\
(0.27)\end{array}$ & $\begin{array}{l}1.286 \\
(0.93)\end{array}$ & $\begin{array}{l}3.222 \\
(1.07)\end{array}$ & $\begin{array}{l}0.537 \\
(0.34)\end{array}$ & $\begin{array}{l}1.540 \\
(0.28)\end{array}$ \\
\hline Debt & $\begin{array}{l}1.089 \\
(1.55) \\
\end{array}$ & $\begin{array}{l}0.261 \\
(0.42) \\
\end{array}$ & $\begin{array}{l}-0.399 \\
(-0.40) \\
\end{array}$ & $\begin{array}{l}0.396 \\
(0.66) \\
\end{array}$ & $\begin{array}{l}0.427 \\
(0.42) \\
\end{array}$ & $\begin{array}{l}1.228^{*} \\
(1.68) \\
\end{array}$ & $\begin{array}{l}3.120 \\
(1.60) \\
\end{array}$ \\
\hline CAPEX & $\begin{array}{l}-2.060 \\
(-0.67) \\
\end{array}$ & $\begin{array}{l}1.221 \\
(0.40) \\
\end{array}$ & $\begin{array}{l}1.470 \\
(0.33) \\
\end{array}$ & $\begin{array}{l}1.091 \\
(0.37) \\
\end{array}$ & $\begin{array}{l}12.493 * * * \\
(2.73) \\
\end{array}$ & $\begin{array}{l}-1.906 \\
(-0.61)\end{array}$ & $\begin{array}{l}0.125 \\
(-0.69)\end{array}$ \\
\hline $\operatorname{Ln}($ Firm Age $)$ & $\begin{array}{l}-0.086 \\
(-0.58) \\
\end{array}$ & $\begin{array}{l}0.441^{*} \\
(1.69)\end{array}$ & $\begin{array}{l}-0.396 * * \\
(-2.56)\end{array}$ & $\begin{array}{l}0.315 * * \\
(2.14)\end{array}$ & $\begin{array}{l}0.437 \\
(1.29)\end{array}$ & $\begin{array}{l}-0.114 \\
(-0.79)\end{array}$ & $\begin{array}{l}0.890 \\
(-0.78)\end{array}$ \\
\hline Delaware & $\begin{array}{l}0.309 \\
(1.27) \\
\end{array}$ & $\begin{array}{l}0.131 \\
(0.49) \\
\end{array}$ & $\begin{array}{l}-0.005 \\
(-0.01) \\
\end{array}$ & $\begin{array}{l}0.374^{*} \\
(1.82) \\
\end{array}$ & $\begin{array}{l}0.019 \\
(0.04) \\
\end{array}$ & $\begin{array}{l}0.322 \\
(1.31) \\
\end{array}$ & $\begin{array}{l}1.387 \\
(1.38) \\
\end{array}$ \\
\hline S\&P Industrial Index & $\begin{array}{l}0.499 \\
(1.38) \\
\end{array}$ & $\begin{array}{l}-0.564 \\
(-1.18) \\
\end{array}$ & $\begin{array}{l}-0.438 \\
(-0.67) \\
\end{array}$ & $\begin{array}{l}0.802 * * * \\
(2.79)\end{array}$ & $\begin{array}{l}-0.621 \\
(-1.08) \\
\end{array}$ & $\begin{array}{l}0.478 \\
(1.27) \\
\end{array}$ & $\begin{array}{l}1.569 \\
(1.24) \\
\end{array}$ \\
\hline Exchange Listing & $\begin{array}{l}-0.323 \\
(-0.70) \\
\end{array}$ & $\begin{array}{l}-0.173 \\
(-0.51) \\
\end{array}$ & $\begin{array}{l}-0.234 \\
(-0.35) \\
\end{array}$ & $\begin{array}{l}0.069 \\
(0.21) \\
\end{array}$ & $\begin{array}{l}0.757 \\
(1.08) \\
\end{array}$ & $\begin{array}{l}-0.288 \\
(-0.64) \\
\end{array}$ & $\begin{array}{l}0.862 \\
(-0.32) \\
\end{array}$ \\
\hline Ln (Delta) & & & & & & $\begin{array}{l}0.004 \\
(0.53)\end{array}$ & $\begin{array}{l}1.004 \\
(0.57)\end{array}$ \\
\hline Ln (Vega) & & & & & & $\begin{array}{l}0.169 \\
(1.06) \\
\end{array}$ & $\begin{array}{l}1.135 \\
(0.87) \\
\end{array}$ \\
\hline Board Size & & & & & & $\begin{array}{l}0.071 \\
(1.29)\end{array}$ & $\begin{array}{l}1.070 \\
(1.29)\end{array}$ \\
\hline Percent Independent & & & & & & $\begin{array}{l}0.208 \\
(0.71)\end{array}$ & $\begin{array}{l}0.628 \\
(-0.55)\end{array}$ \\
\hline CEO/Chair & & & & & & $\begin{array}{l}-0.532 \\
(-0.59) \\
\end{array}$ & $\begin{array}{l}1.208 \\
(0.67) \\
\end{array}$ \\
\hline Intercept & $\begin{array}{l}-8.705 * * * \\
(-7.77)\end{array}$ & $\begin{array}{l}-8.298 * * * \\
(-5.09)\end{array}$ & $\begin{array}{l}-9.746 * * * \\
(-5.39)\end{array}$ & $\begin{array}{l}-8.129 * * * \\
(-6.47)\end{array}$ & $\begin{array}{l}-12.901 * * * \\
(-7.29)\end{array}$ & $\begin{array}{l}-8.351 * * * \\
(-6.75)\end{array}$ & N.A. \\
\hline Adj. $R^{2}$ & 0.119 & 0.110 & 0.154 & 0.106 & 0.178 & 0.129 & 0.074 \\
\hline $\mathrm{N}$ & 5,050 & 5,050 & 5,050 & 5,050 & 5,050 & 5,050 & 5,050 \\
\hline
\end{tabular}

The numbers in parentheses are heteroscedasticity-robust z-statistics. All final variables are winsorized at the $1^{\text {st }}$ and $99^{\text {th }}$ percentiles. $* * * * *$, and $*$ denote significance at the $1 \%, 5 \%$, and $10 \%$ levels, respectively.

This partial elimination of anti-takeover provisions suggests that some anti-takeover provisions may be not as value-destroying as previously perceived.

We also estimate the hazard model in model (7). The coefficient on High Pension indicates that the presence of high pension fund ownership increases the likelihood of board declassification by $60.6 \%$. 


\section{MlMacrothink}

Business and Economic Research

ISSN 2162-4860

2016, Vol. 6, No. 2

The result indicates that effective monitoring by pension funds triggers the decision to abolish classified boards. Given that shareholder proposals sponsored by large institutional investors enhance the chance of success (Gillan and Starks, 2000), our result is consistent with the finding in Guo, Kruse, and Nohel (2008), who document that shareholder activism plays an important role in eliminating classified boards.

Pension funds appear to target a particular anti-takeover provision. If pension funds view that classified boards entrench management, this illustrates one possible channel through which the external governance force act to enhance firm value by altering corporate governance practices. Nonetheless, it is questionable as about why the active pension funds still do not eliminate entire anti-takeover provisions, knowing that anti-takeover provisions hurt firm value. This partial elimination of anti-takeover provisions suggests that some anti-takeover provisions may be not as value-destroying as perceived.

\section{Conclusion}

The wealth effect of anti-takeover provisions is as yet inconclusive. It appears that the adverse impact of anti-takeover provisions disappears in subsequent years after the 1990's. We explore the influence of external monitoring mechanisms in abolishing anti-takeover provisions. Our evidence shows that public pension funds play an important role in shaping corporate governance structure by promoting firms to abolish their anti-takeover provisions. The most notable finding is that the presence of public pension funds is associated with the elimination of classified boards in a firm. The finding suggests that public pension funds serve as an effective monitor in eliminating value-destructive anti-takeover provisions. It is noted that public pension funds do not eliminate the entire anti-takeover provisions. This reflects a firm-specific tradeoff between benefits and costs of anti-takeover provisions and there exist optimal mixtures of anti-takeover defenses that can maximize shareholder wealth.

\section{References}

Bebchuk, L., Cohen, A., \& Ferrell, A. (2009). What matters in corporate governance? Review of Financial Studies, 22, 783-827. http://dx.doi.org/10.1093/rfs/hhn099

Bertrand, M., \& Mullainathan, S. (2003). Enjoying the quiet life? Managerial behavior following anti-takeover legislation, Journal of Political Economy, 111, 1043-1075.

Core, J., Guay, W., \& Rusticus, T. (2006). Does weak governance cause weak stock returns? An examination of firm operating performance and investors' expectations, Journal of Finance, 61, 655-687. http://dx.doi.org/10.1111/j.1540-6261.2006.00851.x

Cremers, M., \& Nair, V. (2005). Governance mechanisms and equity prices, Journal of Finance, 60, 2859-2894. http://dx.doi.org/10.1111/j.1540-6261.2005.00819.x

Dittmar, A., \& Mahrt-Smith, J. (2007). Corporate Governance and the Value of Cash Holdings, Journal of Financial Economics, 83, 599-634.

http://dx.doi.org/10.1016/j.jfineco.2005.12.006

Gillan, S., \& Starks, L. (2000). Corporate governance proposals and shareholder activism: 


\section{Macrothink}

Business and Economic Research

ISSN 2162-4860

2016, Vol. 6, No. 2

The role of institutional investors, Journal of Financial Economics, 57, 275-305. http://dx.doi.org/10.1016/S0304-405X(00)00058-1

Giroud, X., \& Mueller, H. (2010). Does corporate governance matter in competitive industries?, Journal of Financial Economics, 95, 312-331.

http://dx.doi.org/10.1016/j.jfineco.2009.10.008

Gompers, P., Ishii, J., \& Metrick, A. (2003). Corporate governance and equity prices, Quarterly Journal of Economics, 118, 107-155.

http://dx.doi.org/10.1162/00335530360535162

Gompers, P., \& Metrick, A. (2001). Institutional investors and equity prices, Quarterly Journal of Economics, 116, 229-259. http://dx.doi.org/10.1162/003355301556392

Guo, R., Kruse, T., \& Nohel, T. (2008). Undoing the powerful anti-takeover force of staggered boards, Journal of Corporate Finance, 14, 274-288.

http://dx.doi.org/10.1016/j.jcorpfin.2008.03.007

Harford, J., Mansi, S., \& Maxwell, W. (2008). Corporate governance and firm cash holdings in the US, Journal of Financial Economics, 87, 535-555.

http://dx.doi.org/10.1016/j.jfineco.2007.04.002

Kim, E., \& Lu, Y. (2011). CEO ownership, external governance, and risk-taking, Journal of Financial Economics, 102, 272-292. http://dx.doi.org/10.1016/j.jfineco.2011.07.002

Masulis, R., Wang, C., \& Xie, F. (2007). Corporate governance and acquirer returns, Journal of Finance, 62, 1851-1889. http://dx.doi.org/10.1111/j.1540-6261.2007.01259.x

Shleifer, A., \& Vishny, R. (1997). A survey of corporate governance, Journal of Finance, 52, 737-783. http://dx.doi.org/10.1111/j.1540-6261.1997.tb04820.x

\section{Copyright Disclaimer}

Copyright for this article is retained by the author(s), with first publication rights granted to the journal.

This is an open-access article distributed under the terms and conditions of the Creative Commons Attribution license (http://creativecommons.org/licenses/by/3.0/).

\footnotetext{
i Masulis, Wang, and Xie (2007) find that acquisition performance is poor for dictatorship acquirers compared to democratic acquirers. Governance indices are also associated with less valuable cash holdings (Dittmar and Mart-Smith, 2007; Harford, Mansi, and Maxwell, 2008).

ii Core, Guay, and Rusticus (2006) also find that the trading strategy similar to that of Gompers et al. (2003) does not yield abnormal returns during the 2000-2003 period.
} 